\title{
Administrative mechanisms for resolving individual labour disputes in foreign countries
}

\author{
Aleksei Vladimirovich $\operatorname{Iglin}^{1}$ \\ University of Finance under the Government of the Russian Federation, Department of Legal \\ Regulation of Economic Activities, Moscow, Russia
}

\begin{abstract}
According to international labor standards, the labor-management system covers all public administration bodies responsible for and/or involved in labor-management, whether they are ministerial departments or government agencies, including semipublic, regional, or local agencies, or any other form of decentralized administration, and any institutional framework for coordinating the activities of such bodies and for consultation and participation of employers and employees and their organization. In this regard, dispute resolution mechanisms through administrative departments and agencies, labor inspections, and voluntary compliance are most pronounced. The purpose of the study was to conduct a comprehensive analysis of administrative mechanisms for resolving individual labor disputes in foreign countries; to draw conclusions about the effectiveness, prospects, and legal clarity of coordination of labor disputes. When conducting research the author relies on foreign doctrine, the practice of the subjects involved in labor relations, acts of foreign legislation. Research methods: a dialectical approach to the knowledge of administrative mechanisms, allowing analyzing them in their practical development and functioning in the context of coordination of labor legal relations. The comparative legal method and dialectics determined the choice of specific research methods: comparative and formal-legal. The functions, jurisdiction, and procedures of individual labor dispute resolution mechanisms and labor inspectorates are the subject of comprehensive research because of their effectiveness in protecting workers' rights. The article provides a detailed comparative legal analysis of the specifics of dispute resolution through administrative departments and agencies, the role of labor inspections/law enforcement, and access to justice for workers in unclear or hidden employment relationships. On the basis of a large array of regulative sources, the author concludes about the importance of administrative mechanisms in the proper enforcement of labor laws abroad.
\end{abstract}

Keywords: labor disputes, labor inspections, employees, employers, foreign administrations, conciliation

\section{Introduction}

${ }^{1}$ Corresponding author: iglin-av@list.ru 
In many countries, labor-management systems play an important role in the effective organization and operation of individual labor dispute prevention and resolution systems. They are not only responsible for the mechanisms in place to prevent and resolve disputes, but also for providing free dispute resolution services, such as conciliation/mediation, and for providing a range of preventive services through information, advice, and education that encourage voluntary dispute resolution and voluntary compliance with agreements. In some countries, this includes court decisions. In many countries, such services are provided by labor departments or state administrative agencies.

\section{Methods}

The functions, jurisdiction, and procedures of individual labor dispute resolution mechanisms and labor inspectorates in the countries under consideration differ considerably. In particular, the approach to non-payment or underpayment of wages is radically different: in some countries, the recovery of unpaid wages is essentially the subject of an individual labor dispute (civil action), while in others it becomes the subject of enforcement through the inspectorate. The diversity of national perspectives on this issue indicates the importance of establishing a balanced relationship between dispute resolution mechanisms and labor inspectorates to ensure respect for the rule of law and the proper functioning of individual labor dispute resolution systems.

\section{$3 \quad$ Results and discussion}

Obviously, most administrative services filter a large volume of individual labor disputes out of litigation and offer a free, affordable, and much quicker settlement. However, the growth and development of these services raise questions about the degree of state intervention required to prevent and resolve labor disputes, especially when collective expression mechanisms ("collective voice" mechanisms) are absent or dysfunctional, or their role in addressing individual grievances is legally limited.

For a correct comparison of the studied administrative mechanisms, the following components shall be distinguished.

\subsection{Resolution of disputes through administrative departments and agencies}

In Japan, for example, the Labor Administration offers three basic services free of charge: (a) unified counseling offices located in each prefecture that offer counseling and information services (dispute resolution options, settlement procedures, applicable laws and regulations); (b) administrative guidance; and (c) conciliation by dispute adjustment commissions (DACs) created in each prefecture and composed of three neutral experts in labor and employment law. These services appeared relatively recently, in the early 2000 s, due to a dramatic increase in the number of cases in the civil courts involving individual labor disputes. Dispute adjustment commissions (DACs) provide voluntary conciliation if both parties agree [1]. Employers, for example, often refuse to participate in this process. This procedure is used more often by non-standard workers (part-time workers, freight forwarders, or fixed-term contract workers) than by standard workers [2].

In the United States, the Equal Employment Opportunity Commission (EEOC) is an administrative agency that provides pre-trial mediation and conciliation for discrimination claims. The EEOC was established on July 2, 1965, and operates under Section VII of the Civil Rights Act of 1964 [3]. Most discrimination claims shall first be filed with the EEOC 
before they can be filed in federal court. Upon filing an accusation, an investigator is assigned and the employer is notified. Some cases are deemed not worthy of attention and are terminated almost immediately. Otherwise, many EEOC offices will invite parties to participate in a voluntary mediation process. If the case is not successfully resolved, an investigation is conducted in which both parties will be required to present information relevant to the lawsuit. The EEOC reports that the investigation process takes almost ten months on average [4]. Once completed, the EEOC will determine whether there is "reasonable cause" to believe that unlawful discrimination has occurred. If not, the charge is dismissed and the worker is notified that he or she has 90 days to file suit to federal court. Statistics show a low degree of effectiveness of this administrative agency in protecting the rights of U.S. workers: in 2015, the EEOC resolved nearly 64,000 Section VII complaints, with $67 \%$ of them found to be "frivolous" and another $16 \%$ withdrawn by complainants, without receiving any relief, or closed by the agency for administrative reasons [5]. Thus, on the one hand, the EEOC's mandatory labor dispute process is positive for the employee, since the commission undertakes to mediate and investigate the circumstances of the dispute, but, on the other hand, this body is an incumbrance to access to justice, acting as a barrier to workers' filing claims in the federal courts.

In Germany, claims with regard to discrimination and "harassment" in the workplace have been handled by the Federal Anti-Discrimination Agency since 2006 (on the basis of the federal General Equal Treatment Act dd. August 14, 2006) [6].

In Spain, pre-trial administrative conciliation is mandatory for individual labor disputes in the private sector, with some exceptions for certain jurisdictions. Unjustified absence on the part of either party will result in a fine. The conciliation procedure does not take more than 10-15 minutes. In Spain, the process is used for the bureaucratic administrative registration of settlement agreements or for access to unemployment benefits or to apply to the courts. In Spain there has been a significant increase in the use of conciliation since the reform of labor law in 1994 and changes in administrative conciliation in 2011. In 2013, of all the individual cases referred to administrative mediation, most were abandoned or cases were withdrawn (39.5 percent) or closed without an agreement (37 percent), and only 23.5 percent of cases were resolved [7]. The limited functioning of administrative conciliation in Spain, however, has served as an incentive for the social partners to encourage bilateral voluntary settlements, which have long been limited by legal constraints [8].

\subsection{The role of labor inspections / law enforcement agencies}

Regardless of the various services that may exist to provide access to dispute resolution mechanisms, there are many workers who will not pursue claims themselves, even if they work under abusive and inhumane conditions [9]. Thus, labor inspections are usually given broad powers, including the right to enter premises day and night and to impose or initiate sanctions. However, the ultimate goal of labor inspections is usually not to punish conscientious employers who are unaware of their legal responsibilities but are willing to comply with labor protection laws. The general purpose of labor inspections is to promote compliance with labor law, and enforcement actions are used primarily where necessary to achieve this goal.

\subsection{Approaches to encourage voluntary compliance with labor law}

Various approaches, including preventive measures, inspection visits, "remedial" recommendations or orders, are used to encourage compliance with labor law, in order to give the employer the opportunity to correct actions related to violations and at the same 
time speed up the process. The latter approach is consistent with informal dispute resolution in some circumstances [10]. In some of the countries described in this paragraph, such approaches include the use of conciliation/mediation, further blurring the lines between law enforcement and dispute resolution. This is especially true when complex scenarios arise in which it is not easy to clearly define violations or the distinction between them and disputes [11]. However, coercive measures in their full force are applied only in cases of serious violations, abusive and exploitative working conditions, and employers' refusal to comply with recommendations or orders of the labor inspectorate.

Sometimes employers are offered the opportunity to correct violations. The Labor Inspectorate of Japan, when certain violations are found, gives administrative instructions or recommendations that require employers to correct violations and report them to the Labor Inspectorate. Although there is a clear separation of jurisdiction between the labor inspectorate and individual labor dispute resolution procedures, the inspectors' recommendations for remediation often result in dispute resolution [12].

In Australia, Canada, Spain, and the United States, dispute resolution options are included in labor inspectorate procedures as an important step before enforcement. In Australia, the Fair Work Ombudsman (FWO) investigation process involves three steps: (1) assessment of the complaint; (2) resolution of disputes by the Labor Ombudsman's mediators (mediators), primarily through telephone services; and (3) review of enforcement options by labor inspectors [13].

"Naming and shaming" employers is another approach used to encourage labor law compliance, including in the United Kingdom. In the latter case, it is usually used because enforcement mechanisms exist only in very limited areas and are usually weak. But even this approach is limited in its application: in 2015, only 37 employers were "named and shamed" in a UK Government press release [14]. According to British legal scholars Jones and Prassle, despite various efforts to encourage labor law compliance, the vast majority of minimum wage violations stay undetected [15].

\section{Conclusion}

In conclusion, it should be pointed out that both dispute resolution agencies and/or labor inspections are increasingly focusing on information and consultation in their services. The goal is to encourage voluntary compliance with labor law and voluntary dispute resolution. The number of inquiries implies a broad user demand for such services. Cooperation between the individual labor dispute resolution mechanisms and the labor inspectorate is also well established through counseling offices. For example Inspections in Canada and the United States often provide information in several languages. Information is also disseminated through educational events and public awareness campaigns.

\section{References}

1. R. Yamakawa, Japan, in M. Ebisui, S. Cooney, C. Fenwick (eds.), Resolving individual labour disputes: a comparative overview (International Labour Office, Geneva, 2016)

2. A. Forsyth, Australia, in M. Ebisui, S. Cooney, C. Fenwick (eds.), Resolving individual labour disputes: a comparative overview (International Labour Office, Geneva, 2016)

3. Title VII of the Civil Rights Act of 1964. Accessed on: July 09, 2021. [Online]. Available: https://www.ilo.org/wcmsp5/groups/public/---ed_protect/---protrav/---ilo_aids/docume nts/legaldocument/wcms_127765.pdf 
4. What You Can Expect After You File a Charge Accessed on: July 09, 2021. [Online]. Available: https://www.eeoc.gov/employees/process.cfm

5. A. Halegua, United States, in M. Ebisui, S. Cooney, C. Fenwick (eds.), Resolving individual labour disputes: a comparative overview (International Labour Office, Geneva, 2016)

6. Allgemeine Gleichbehandlungsgesetz [General Equal Treatment Act]. Accessed on: July 09, 2021. [Online]. Available: https://www.gesetze-im-internet.de/englisch_agg/index.html

7. A.G. Hernández, Spain, in M. Ebisui, S. Cooney, C. Fenwick (eds.), Resolving individual labour disputes: a comparative overview. (International Labour Office, Geneva, 2016)

8. A.V. Iglin, Labor Law in Russia and Abroad, 3, 60-63 (2016)

9. E. Minawa, S. Cooney, C. Fenwick, Resolving individual labour disputes: a general introduction, in M. Ebisui, S. Cooney, C. Fenwick (eds.), Resolving individual labour disputes: a comparative overview (International Labour Office, Geneva, 2016)

10. F. Steadman, Handbook on Alternative Labour Dispute Resolution. Accessed on: July 09, 2021. [Online]. Available:

http://citeseerx.ist.psu.edu/viewdoc/download?doi=10.1.1.516.3538\&rep=rep1\&type= pdf

11. A.J. Colvin, Grievance procedures in non-union firms, in W.K. Roche, P. Teague, A.J.S. Colvin (eds.), The Oxford handbook of conflict management in organizations. (Oxford University Press, Oxford, 2014)

12. 2016 Annual Labour Standards Inspection Report, vol. 68. Accessed on: August 12, 2021. [Online]. Available:

https://www.mhlw.go.jp/bunya/roudoukijun/kantoku01/dl/28.pdf

13. Fair Work Ombudsman (FWO). Annual report 2013-14. Accessed on: July 09, 2021. [Online]. Available:

https://www.fairwork.gov.au/ArticleDocuments/710/fair-work-ombudsman-annual-rep ort-2013-14.pdf.aspx

14. Government names and shames 37 National Minimum Wage offenders. Accessed on: July 09, 2021. [Online]. Available:

https://www.gov.uk/government/news/government-names-and-shames-37-national-min imum-wage-offenders

15. B. Jones, J. Prassl, United Kingdom, in M. Ebisui, S. Cooney, C. Fenwick (eds.), Resolving individual labour disputes: a comparative overview (International Labour Office, Geneva, 2016) 